\title{
Effect of haemin limitation on the cytochrome complement and glucose metabolism of non-typable Haemophilus influenzae
}

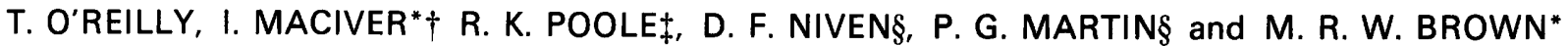

Pharma Research, K125.1.04, CIBA-GEIGY Limited, Basel, Switzerland CH-4002, *Microbiology Research Group, Pharmaceutical Sciences Institute, Aston University, Aston Triangle, Birmingham B4 7ET, $\ddagger$ Division of Biosphere Sciences, King's College, London W8 7AH and \$Department of Microbiology, McGill University, Macdonald Campus, Ste Anne de Bellevue, Québec, Canada H9X $1 \mathrm{CO}$

\begin{abstract}
Summary. Haemophilus influenzae grown to exponential phase or stationary phase in medium with a low initial concentration of haemin $(0.25 \mu \mathrm{g} / \mathrm{ml})$ was virtually devoid of cytochromes. Compared with bacteria grown in the presence of excess haemin $(10 \mu \mathrm{g} / \mathrm{ml})$, the haeminlimited organisms failed to respire formate and succinate and, generally, the respiratory rates with other substrates were reduced. However, growth rates were not affected by the haemin supply. Haemin-limited growth was associated with a reduced efficiency of glucose utilisation, in terms of glucose growth yields, and affected the net levels of excreted organic acids. Haemin limitation resulted in reduced acetate and increased succinate accumulation in the culture medium and the novel presence of D-lactate. These results indicate that, in contrast to the phenotype expressed in vitro during conventional cultivation of $H$. influenzae, the haeminlimited phenotype, which may be expressed in vivo, is characterised by a lack of cytochromes and a shift towards a more anaerobic type of metabolism.
\end{abstract}

\section{Introduction}

Haemophilus influenzae is X-factor (and V-factor) dependent and, when it is grown in vitro, $\mathrm{X}$ factor (protoporphyrin IX) is often supplied as haemin. ${ }^{1}$ Growth is possible over a wide range of initial haemin concentrations and, when the organisms are grown aerobically, the haemin supply is reflected by the cytochrome content. ${ }^{2}$ Organisms grown in the presence of excess haemin are rich in cytochromes, but those grown with yield-limiting quantities of haemin are essentially devoid of such pigments. A similar lack of cytochromes is also a feature of $H$. influenzae grown anaerobically, irrespective of the haemin supply. ${ }^{2}$

Non-typable strains of $H$. influenzae are frequently associated with exacerbations of chronic obstructive pulmonary diseases (COPD) and they can be cultured from purulent or mucoid sputum. ${ }^{3}$ Although $H$. influenzae can use protoporphyrin IX, haemin, haemoglobin, haemoglobin-haptoglobin or haem-haemopexin, but not catalase or cytochromes, as sources of porphyrin ring when growing in vitro, ${ }^{4}$ the extent to which porphyrin ring compounds are available to such organisms in the respiratory tract secretions of COPD

Received 26 Sept. 1991; accepted 14 Nov. 1991.

$\dagger$ Present address: Department of Microbiology, Southwestern Graduate School of Biomedical Sciences, University of Texas Health Center at Dallas, Dallas, Texas 75235, USA. patients and healthy individuals is not known. Despite increased serum transudation into the lungs of COPD patients, ${ }^{5}$ it is conceivable that the supply of porphyrin ring compounds suitable for the growth of $H$. influenzae in respiratory tract secretions may be minimal. If this is the case, the phenotype of $H$. influenzae in vivo may be quite different from that of organisms grown in vitro in the presence of excess haemin. With this in mind, the aims of the present study were to use haemin limitation to mimic the putative in-vivo environment, to examine the effects of haemin limitation on some aspects of $H$. influenzae energetics and metabolism, and so to gain a better appreciation of the possible metabolic status of the in-vivo-grown organism.

\section{Materials and methods}

\section{Organisms and growth conditions}

$H$. influenzae strain HM3, most used in this study, was isolated from the sputum of a patient with bronchiectasis and confirmed as non-typable by its failure to agglutinate in the presence of capsule-specific antisera; it was found to be biotype 3 by standard biochemical tests. Other strains used were clinical isolates, except for strain Eagon which was obtained from Dr P. Williams (University of Nottingham); of 
these additional strains, three were non-typable and two were capsular serotype b. The bacteria were stored frozen $\left(-70^{\circ} \mathrm{C}\right)$ in glycerol-supplemented $(15 \% \mathrm{v} / \mathrm{v}$ final concentration) Brain Heart Infusion Broth (BHI; Lab M).

Bacteria from chocolate-agar plates were used to inoculate $20-\mathrm{ml}$ volumes of haemin $(10 \mu \mathrm{g} / \mathrm{ml})-$ and NAD $(10 \mu \mathrm{g} / \mathrm{ml})$-supplemented BHI in $125-\mathrm{ml}$ conical flasks. After incubation (18 h), such cultures were used to inoculate $(0 \cdot 1 \% \mathrm{v} / \mathrm{v})$ either $20-\mathrm{ml}$ volumes, for growth yield determinations, or $200-\mathrm{ml}$ volumes, for the preparation of bacterial suspensions and extracts, of $\mathrm{BHI}$ in $125-\mathrm{ml}$ or $1-\mathrm{L}$ conical flasks, respectively. To determine the growth yield for haemin, the BHI was supplemented with excess NAD $(10 \mu \mathrm{g} / \mathrm{ml})$ and various quantities of haemin. To determine the growth yield for glucose, the BHI was "glucose-free" (kindly provided by $\mathrm{Lab} \mathrm{M}$ ) and the autoclaved medium was supplemented with NAD $10 \mu \mathrm{g} / \mathrm{ml}$ and haemin 10 or $0.25 \mu \mathrm{g} / \mathrm{ml}$, and various quantities of filter-sterilised glucose. To obtain bacteria for suspensions or extracts, the BHI was supplemented with haemin to give concentrations that did $(0.25 \mu \mathrm{g} / \mathrm{ml})$ or did not (10 $\mu \mathrm{g} / \mathrm{ml})$ affect the final growth yield, and NAD was present in excess $(10 \mu \mathrm{g} / \mathrm{ml})$; alternatively, haemin was present in excess $(10 \mu \mathrm{g} / \mathrm{ml})$ and the initial NAD concentration was reduced to $0 \cdot 1 \mu \mathrm{g} / \mathrm{ml}$, so that the NAD supply determined the extent of growth. All cultures were incubated at $37^{\circ} \mathrm{C}$ in an atmosphere not enriched with $\mathrm{CO}_{2}$; liquid cultures were shaken (180 rpm) and growth was monitored by spectrophotometry at $470 \mathrm{~nm}$ with diluted samples, as appropriate.

\section{Preparation of bacterial suspensions and extracts}

Bacteria from exponential phase or stationary phase cultures of $H$. influenzae were used to prepare bacterial suspensions essentially as described for $H$. parasuis. ${ }^{6}$ Such suspensions were used either untreated or to prepare cell-free extracts and particulate (membraneenriched) and soluble (cytoplasm plus periplasm) fractions, again as described for $H$. parasuis $^{6}$ except that a French pressure cell operating at $1 \cdot 1 \times 10^{5} \mathrm{kPa}$ was used to disrupt the bacteria. The entire supernatant fraction resulting from the ultracentrifugation of each cell-free extract was retained. Protein was determined by the method of Peterson ${ }^{7}$ with bovine serum albumin as a standard.

\section{Cytochrome difference spectra}

Cytochrome difference spectra were measured by the general methods described by Poole and Bashford. ${ }^{8}$ A Perkin-Elmer spectrophotometer (model 356) was used to collect the quantitative data; similar data were obtained with a Johnson Foundation SDB-3 spectrophotometer. Sodium dithionite was the reductant and either air (shaking), ammonium persulphate, or $\mathrm{Na}_{3} \mathrm{Fe}(\mathrm{CN})_{6}$ was used as oxidant; these oxidants were associated with equivalent extents of sample oxidation. To obtain carbon monoxide difference spectra, the samples, as appropriate, were bubbled with a stream of $\mathrm{CO}$ for $2 \mathrm{~min}$. Cytochrome quantitation was performed with peak (or shoulder)-trough wavelength pairs and the extinction coefficients given by Jones and Redfearn. ${ }^{9}$

\section{Determination of respiratory rates}

Respiration was measured at $30^{\circ} \mathrm{C}$ with an oxygen electrode (Rank Bros, Bottisham, Cambridge) coupled to a chart recorder. The incubation mixture contained bacterial suspension, cell-free extract or particulate fraction, with phosphate-buffered saline (PBS) ${ }^{6}$ to a total volume of $2.97 \mathrm{ml}$. The reaction was initiated by the addition of $0.03 \mathrm{ml}$ of substrate in PBS; except for glucose $(10 \mathrm{mM})$, the final substrate concentrations were $1 \mathrm{~mm}$. The results were corrected for endogenous respiratory activity obtained under identical conditions of assay.

\section{Identification of acid end-products of glucose metabolism}

The identities and quantities of organic acids released by $H$. influenzae were determined with culture supernates derived from stationary phase cultures grown in the presence of initial haemin concentrations that did $(0.25 \mu \mathrm{g} / \mathrm{ml})$ or did not $(10 \mu \mathrm{g} / \mathrm{ml})$ determine the final growth yield; NAD was present in excess $(10 \mu \mathrm{g} / \mathrm{ml})$. Bacteria were removed from cultures by centrifugation (Eppendorf centrifuge; $13000 \mathrm{~g}, 2 \mathrm{~min}$ ) and the resulting supernates were filtered $(0.45 \mu \mathrm{m}$ pore size) and stored frozen $\left(-20^{\circ} \mathrm{C}\right)$.

Qualitative identification of acid end-products relied on methods based on those of Tuyau et al. ${ }^{10}$ Volatile acids were extracted as follows. Each 2-ml volume of culture supernate was treated with $0.2 \mathrm{ml} \mathrm{H}_{2} \mathrm{SO}_{4} 50 \%$ $\mathrm{v} / \mathrm{v} ; \mathrm{NaCl} 0.4 \mathrm{~g}$ was then added and the mixture was extracted with $1.0 \mathrm{ml}$ of diethyl ether. After centrifugation $\left(1000 \mathrm{~g}, 4^{\circ} \mathrm{C}, 10 \mathrm{~min}\right)$, the samples were frozen $\left(-20^{\circ} \mathrm{C}\right)$ and the upper layer from each was removed for analysis; sodium propionate was used as an internal standard. Non-volatile acids were methylated: $2 \mathrm{ml}$ of methanol was added to acidified samples $\left(0.4 \mathrm{ml}\right.$ of $\mathrm{H}_{2} \mathrm{SO}_{4} 50 \% / 1 \mathrm{ml}$ of culture supernate) and the resulting mixtures were incubated for $30 \mathrm{~min}$ at $56{ }^{\circ} \mathrm{C}$. For analysis, the methylated acids were extracted into $0.25 \mathrm{ml}$ of chloroform; sodium malonate was used as an internal standard. A Hewlett Packard 5710A gas liquid chromatograph, with an automatic sampler (model 7671A) which injected $1 \mu \mathrm{l}$ of sample, was used for the analyses. The acids were separated on neophenylglycol succinate $20 \%-\mathrm{H}_{3} \mathrm{PO}_{4}$ $2 \%$ with a Chromosorb P (60-80 mesh) support; the column ( $2 \mathrm{~mm} \mathrm{ID,} \mathrm{glass)} \mathrm{was} \mathrm{maintained} \mathrm{at} 165^{\circ} \mathrm{C}$ and $\mathrm{N}_{2}(20 \mathrm{ml} / \mathrm{min})$ was the carrier gas. Flame ionisation detection was used $\left(200^{\circ} \mathrm{C}\right)$ and the electronic signal was processed by a Hewlett Packard 
3308A integrator. The identity of each organic acid was established by comparing the retention times of the organic acids in extracted culture supernates with those of known organic acids. Quantitation was accomplished by comparing the peak areas obtained with the separated acids from samples with those obtained with standards.

For the determination of D- and L-lactate, culture supernates were diluted 1 in 10 with cold perchloric acid. After $3 \mathrm{~min}$ on ice, the samples were centrifuged $13000 \mathrm{~g}, 3 \mathrm{~min}$ ) and $50-\mu \mathrm{l}$ samples of the resulting supernates were removed for analysis. Lactate was assayed enzymatically by adding 8IU of either Llactate dehydrogenase (beef heart; Boehringer-Mannheim) or D-lactate dehydrogenase (Lactobacillus leichmannii; Sigma) in $1 \mathrm{ml}$ of $0.6 \mathrm{M}$ glycine- $0.5 \mathrm{M}$ hydrazine buffer (pH 8.3; Sigma) containing $10 \mathrm{~mm}$ NAD. Such mixtures were incubated $\left(37^{\circ} \mathrm{C}, 1 \mathrm{~h}\right)$ and the $\Delta \mathrm{A}_{340 \mathrm{~nm}}$ values, which corresponded to $\mathrm{NADH}$ production, were compared with those obtained when solutions of known lactate concentration were treated similarly. Samples did not appear to contain an inhibitor of lactate dehydrogenase and the limit of detection was $0.01 \mathrm{~mm}$ of either diastereoisomer.

Formate was determined enzymatically with a commercial test kit (Boehringer-Mannheim).

\section{Assay of $D$ - and L-lactate dehydrogenase activities}

The lactate dehydrogenase activities of soluble fractions were determined essentially as described by Denicola-Seoane and Anderson. ${ }^{11}$ Subcellular fractions were prepared as described above except that all buffers contained $1 \mathrm{~mm}$ dithiothreitol. Assay mixtures contained $1 \mathrm{~mm}$ NADH, $40 \mathrm{~mm}$ pyruvate and $50 \mathrm{~mm}$

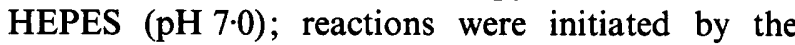
addition of soluble fraction and the results were corrected for non-lactate dehydrogenase-dependent $\mathrm{NADH}$ oxidation (consistently $<0.5 \mathrm{nmol} \mathrm{NADH}$ consumed $/ \mathrm{min} / \mathrm{mg}$ of protein). The identity of the stereoisomer of lactate produced was established with reaction mixtures extracted and assayed as described above.

\section{Results}

Exogenous haemin supply can determine the extent of growth of $H$. influenzae

Progressive reduction in the initial concentration of haemin provided to $H$. influenzae strain HM3 resulted eventually in reduced biomass production and in marked reductions in culture $\mathrm{pH}$ (fig. 1). The latter effect was associated with a lack of re-alkalinisation of the culture medium by haemin-limited organisms in contrast to haemin-replete organisms (fig. 2). Interestingly, a 40-fold reduction in the initial haemin concentration, while reducing the biomass by $60 \%$, had no effect on the mean generation time (fig. 2; haemin-replete, $48 \mathrm{~min}$; haemin-limited, $49 \mathrm{~min}$ ). Similarly, reducing the initial NAD concentration from $10 \mu \mathrm{g} / \mathrm{ml}$ to $0 \cdot 1 \mu \mathrm{g} / \mathrm{ml}$, while reducing the biomass by $42 \%$, had no effect on the growth rate (mean generation time $48 \mathrm{~min}$ ); the mean final $\mathrm{pH}$ of NADlimited cultures was 7.39 SEM 0.05.

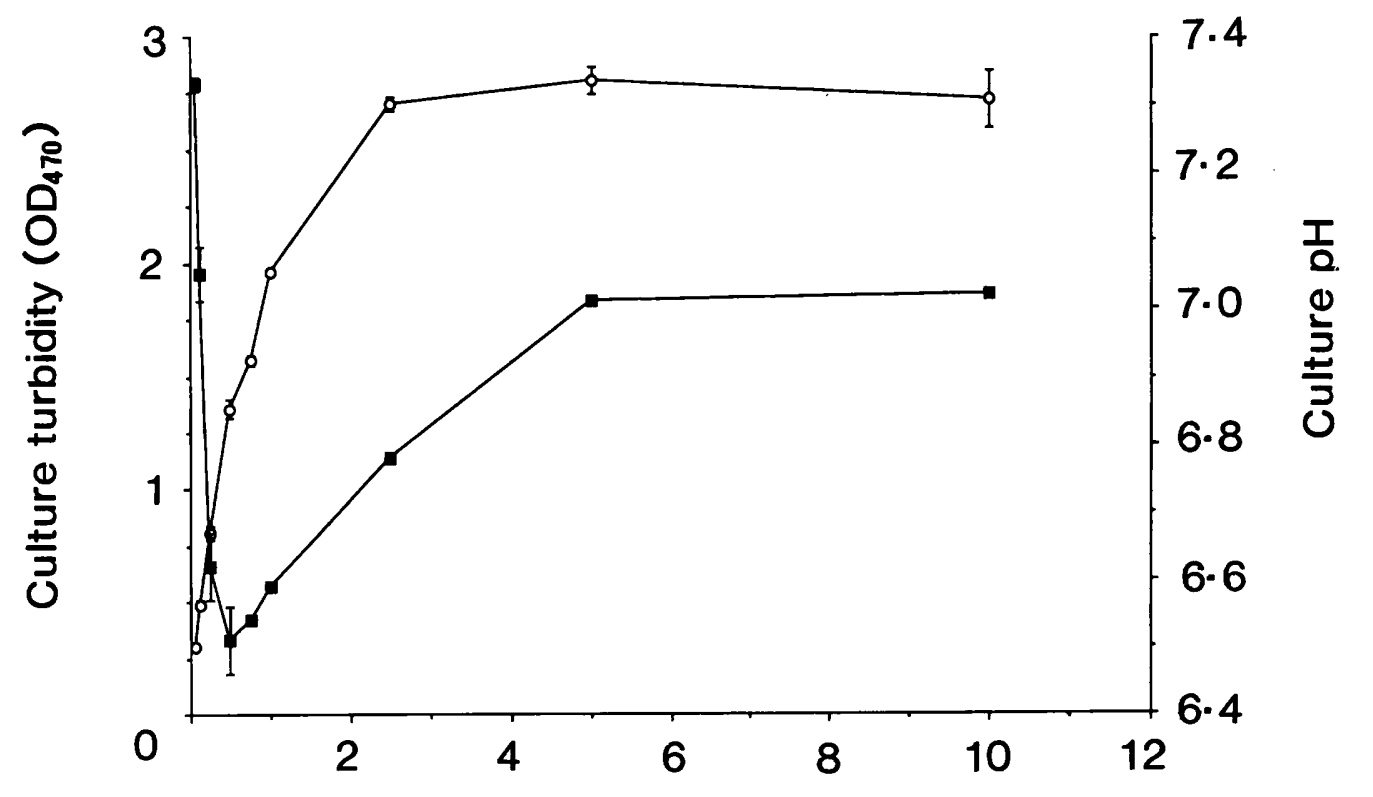

Initial haemin concentration $(\mu \mathrm{g} / \mathrm{ml})$

Fig. 1. Effect of initial haemin concentration on the turbidity and $\mathrm{pH}$ attained by cultures of $H$. influenzae strain HM3 in BHI supplemented with NAD $10 \mu \mathrm{g} / \mathrm{ml}$ and various quantities of haemin. Final optical density measurements $(O)$ and $\mathrm{pH}$ measurements $(\boldsymbol{\square})$ were performed on stationary phase (13-h) cultures. Symbols (and bars) represent mean values $(n=3)$ (and SEM). 


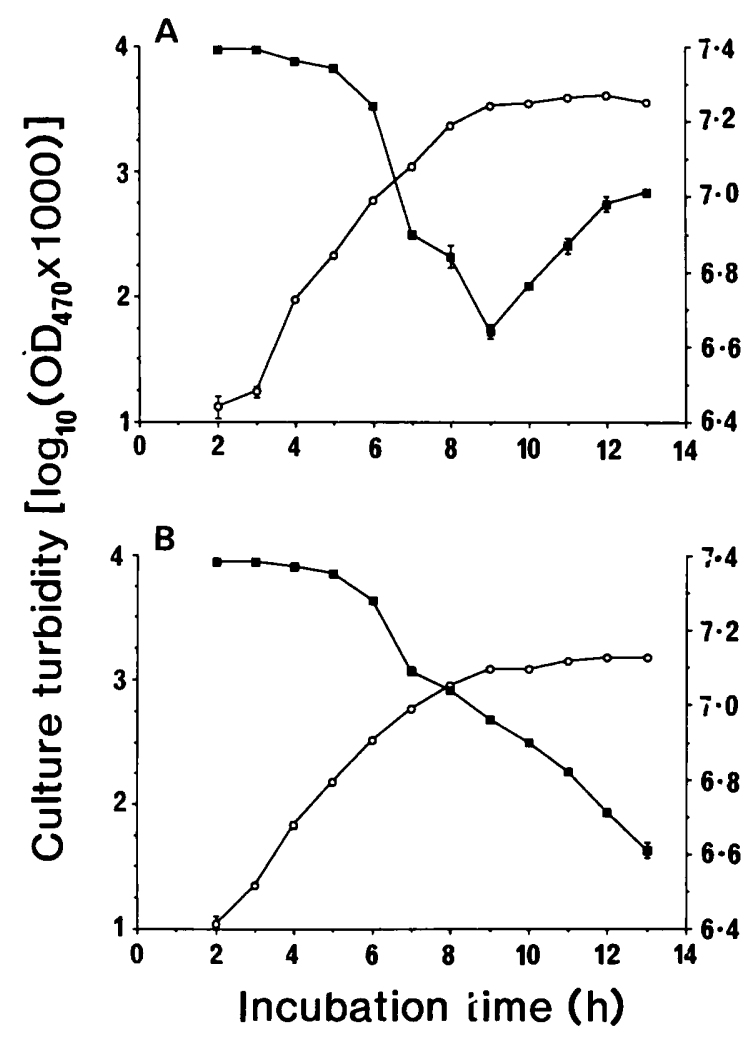

Fig. 2. Effect of initial haemin concentration on the growth cycle and culture $\mathrm{pH}$ of $H$. influenzae strain $\mathrm{HM} 3$ grown in BHI supplemented with NAD $10 \mu \mathrm{g} / \mathrm{ml}$ and haemin either $10(A)$ or 0.25 $\mu \mathrm{g} / \mathrm{ml}(\mathbf{B})$. Symbols depicting measurements of culture turbidity $(O)$ and $\mathrm{pH}(\mathbf{\square})$ represent mean values $(\mathrm{n}=3)$ (vertical bars, SEM).

\section{Haemin limitation reduces the cytochrome content of} H. influenzae

Scanning spectrophotometry in the visible region, with subcellular fractions derived from bacteria grown with excess haemin, revealed several cytochrome types (fig. 3). The reduced minus oxidized spectrum of the crude cell-free extract (trace a) is complex showing several broad, probably multicomponent, peaks centred at 444,528 and $554 \mathrm{~nm}$. The $\alpha$-band at $554 \mathrm{~nm}$ and $\beta$-band at $528 \mathrm{~nm}$ probably arise from $b$ - and $c$ type cytochromes. The origin of the $444-\mathrm{nm}$ band is less clear; the absence of bands near $600 \mathrm{~nm}$ suggest it is not attributable to $a$-type cytochromes. The position of the Soret band at $\mathbf{4 4 4} \mathrm{nm}$ and the broad absorbance at $570 \mathrm{~nm}$ are reminiscent of the purified Escherichia coli haemoprotein $b-590$, a high-spin hydroperoxidase. ${ }^{12} \mathrm{~A}$ shoulder at $630 \mathrm{~nm}$ is indicative of reduced cytochrome $d$; the trough due to the "oxy" form expected at about $650 \mathrm{~nm}$ is presumably obscured by the unidentified but prominent band at $667 \mathrm{~nm}$. The corresponding $\mathrm{CO}$ difference spectrum (trace d) is dominated by peaks at 538 and $569 \mathrm{~nm}$ and a trough at $554 \mathrm{~nm}$. The contributions to these complex signals are more easily determined from the $\mathrm{CO}$ difference spectra of the membrane (trace e) and soluble (trace f) fractions. The positions of the $\gamma$-band maximum (at $412 \mathrm{~nm}$ ) and the $\gamma$-band trough (at $436 \mathrm{~nm}$ ) in trace $\mathrm{f}$ are indicative of $c$-type haem. Furthermore, the
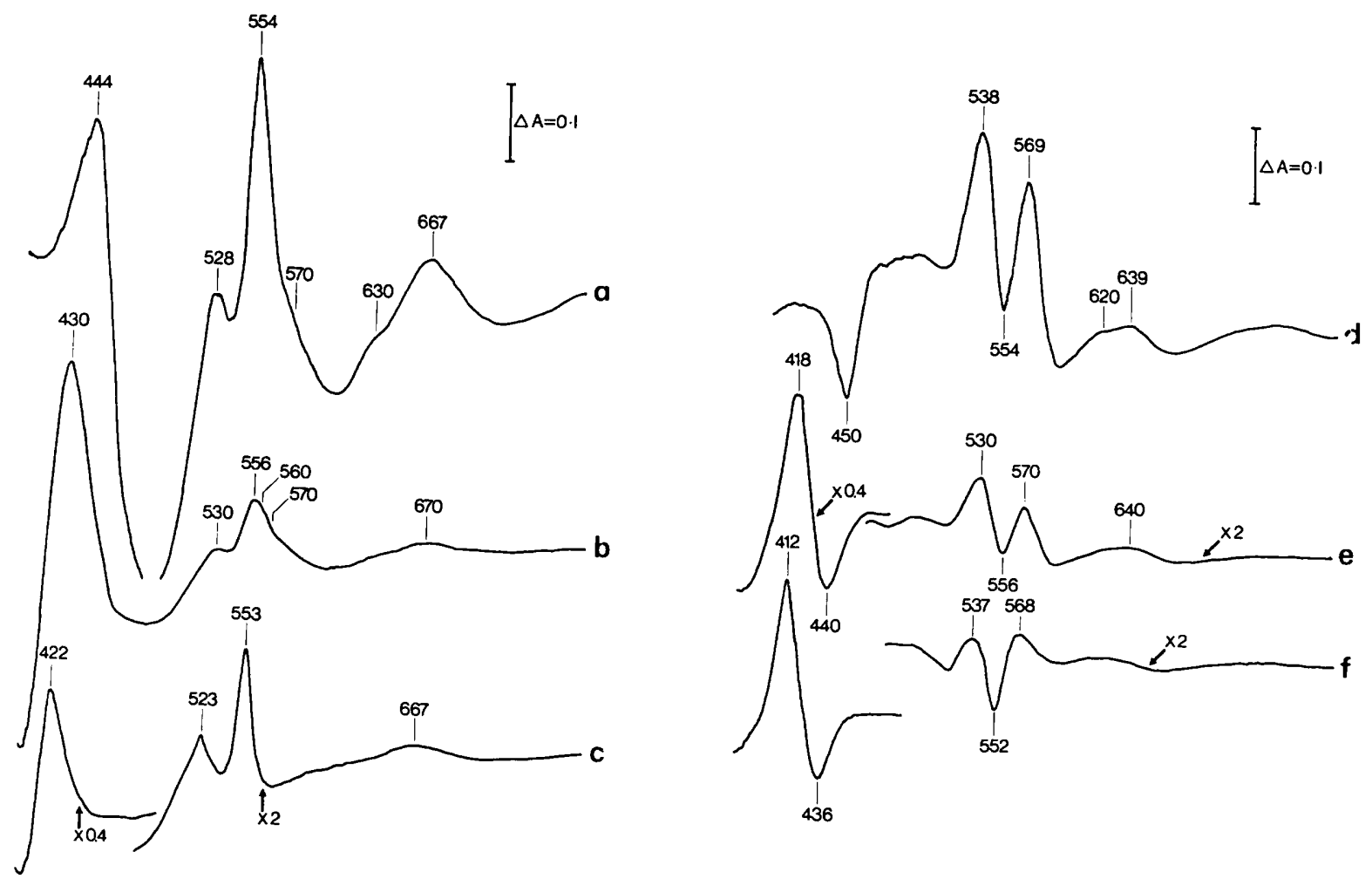

Fig. 3. Difference spectra of subcellular fractions derived from $H$. influenzae strain HM3 grown under haemin-replete conditions: $\mathbf{a}, \mathbf{b}$ and $\mathbf{c}$ are reduced (dithionite) minus oxidised (persulphate) difference spectra; $\mathbf{d}, \mathbf{e}$ and $\mathbf{f}$ are $\mathrm{CO}$-difference spectra [(CO+dithionite-reduced) minus reduced]; $\mathbf{a}$ and $\mathbf{d}$ are of a crude cell-free extract (protein $10 \mathrm{mg} / \mathrm{ml}$ ), $\mathbf{b}$ and e of a particulate (membrane) fraction (protein $2.5 \mathrm{mg} / \mathrm{ml})$ and c and $\mathbf{f}$ of a soluble (cytoplasm plus periplasm) fraction (protein $6 \mathrm{mg} / \mathrm{ml}$ ) derived from bacteria grown to stationary phase under haeminreplete conditions. All spectra were recorded at room temperature with an SDB-3 dual wavelength scanning spectrophotometer at a scan speed of $5.7 \mathrm{~nm} / \mathrm{s}$ and a spectral band width of $4 \mathrm{~nm}$. Appropriate baselines (not shown; oxidised minus oxidised or reduced minus reduced) were recorded but were featureless. 
dominant trough at $552 \mathrm{~nm}$ suggests a low-spin reduced state, ${ }^{13}$ the trough position mirroring the $\alpha$ band of the reduced cytochrome observed at $553 \mathrm{~nm}$ in trace $\mathrm{c}$. The $\mathrm{CO}$ difference spectrum of the membranes (trace e) is less useful because a $\gamma$-band at $418 \mathrm{~nm}$ could be attributed to $b$ - or $c$-type haems. Nevertheless, the $440 \mathrm{~nm}$ trough in trace $e$ and the features of the reduced spectrum (trace b) all suggest $b$-type haem. The shallowness of the 556-nm trough in trace e and the Soret $/ \alpha$ ratio $[(\gamma$ peak $-\gamma$ trough $) /(\alpha$ peak $-\alpha$ trough $)]$ of about 10 suggest a high-spin reduced state. ${ }^{13}$ The CO difference spectrum of the crude extract (trace d)

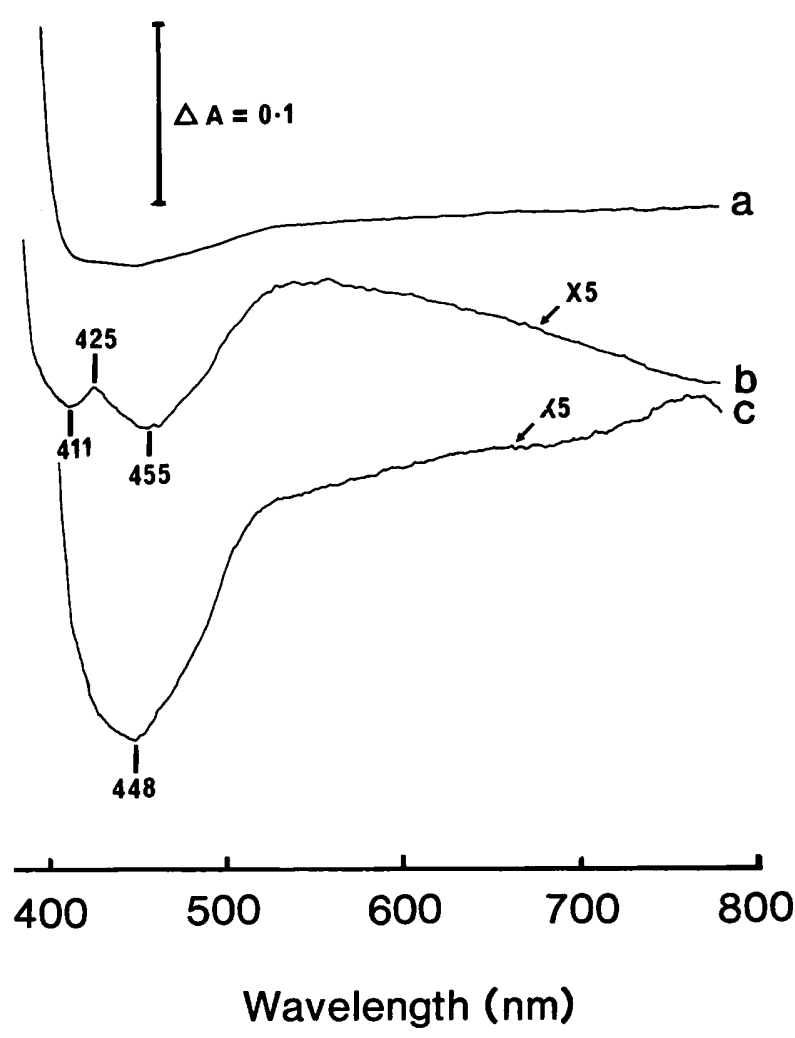

Fig. 4. Difference spectra of subcellular fractions derived from $H$. influenzae strain HM3 grown under haemin-limited conditions. The spectra are reduced minus oxidised difference spectra of: a a cell-free extract (protein $2.4 \mathrm{mg} / \mathrm{ml}$ ): b a particulate fraction (protein 2.5 $\mathrm{mg} / \mathrm{ml}$ ): and c a soluble fraction (protein $6 \mathrm{mg} / \mathrm{ml}$ ) derived from bacteria grown to stationary phase under haemin-limited conditions. Spectral scanning conditions were as in fig. 3 . suggests a trace of a cytochrome $d$-like component with a maximum near $640 \mathrm{~nm}$. In summary, these spectra indicate that $H$. influenzae strain HM3 possesses a cytochrome complement consisting of $b-, c$ and $d$-type cytochromes of which at least a portion of the $c$-type cytochrome(s) is soluble or easily liberated from the membrane.

The reduced minus oxidised difference spectra of fractions derived from haemin-limited bacteria (fig. 4) reveal no cytochromes in either the crude extract (trace a), membranes (trace b) or soluble fraction (trace c). CO difference spectra were also recorded (not shown) and were featureless. The broad, apparently heterogeneous troughs near $450 \mathrm{~nm}$ are probably due to flavins.

Table I summarises the distribution of the cytochromes in the various fractions derived from $H$. influenzae. It is notable that whereas haemin limitation results in profound quantitative changes in the concentrations of the cytochromes in fractions derived from both stationary and exponential phase organisms, without effect on the growth rate (see fig. 2), fractions from NAD-limited organisms are characterised by cytochrome concentrations similar to those obtained with fractions from haemin-replete bacteria. In effect, a simple decrease in final biomass does not appear to be responsible for the observed changes in the cytochrome concentrations.

\section{Haemin limitation reduces, or selectively eliminates, respiratory capacities}

The lack of cytochromes in stationary and exponential phase bacteria was not associated with the complete absence of respiratory metabolism of potential energy sources (table II). For example, haeminlimited, stationary phase bacteria still respired glucose, pyruvate and D- and L-lactate, albeit at rates that were 10-fold less than those exhibited by haemin-replete bacteria, and acetate at a rate that was only three-fold less than that exhibited by haemin-replete organisms. On the other hand, there appeared to be a selective loss in the capacity for formate and succinate respiration by haemin-limited bacteria (table II). Despite the

Table I. Effect of growth conditions and growth phase on the concentrations of cytochromes in cell fractions derived from $H$. influenzae strain HM3

\begin{tabular}{|c|c|c|c|c|c|c|c|c|c|c|}
\hline \multirow{3}{*}{$\begin{array}{l}\text { Growth } \\
\text { conditions }\end{array}$} & \multirow{3}{*}{$\begin{array}{l}\text { Growth } \\
\text { phase }\end{array}$} & \multicolumn{9}{|c|}{ Cytochrome concentrations ( $\mathrm{pmol} / \mathrm{mg}$ of protein) } \\
\hline & & \multicolumn{3}{|c|}{ Cell-free extract } & \multicolumn{3}{|c|}{ Particulate fraction } & \multicolumn{3}{|c|}{ Soluble fraction } \\
\hline & & Cyt. $b$ & Cyt.c & Cyt.d & Cyt. $b$ & Cyt.c & Cyt.d & Cyt. $b$ & Cyt.c & Cyt.d \\
\hline \multirow[t]{2}{*}{ Haemin-replete } & Stationary & 270 & 256 & 40 & 717 & 600 & 93 & ND & 59 & ND \\
\hline & Exponential & 341 & 276 & 93 & 425 & 347 & 70 & ND & 46 & ND \\
\hline \multirow{2}{*}{ Haemin-limited } & Stationary & ND & ND & ND & ND & ND & ND & ND & ND & ND \\
\hline & Exponential & ND & ND & ND & ND & ND & ND & ND & ND & ND \\
\hline NAD-limited & Stationary & 303 & 229 & 75 & 796 & 605 & 51 & ND & 70 & ND \\
\hline
\end{tabular}

ND, none detected. 
Table II. Effect of growth conditions and growth phase on the respiratory activities of intact cells of $H$. influenzae strain HM3

\begin{tabular}{|c|c|c|c|c|c|c|c|c|}
\hline \multirow{2}{*}{$\begin{array}{l}\text { Growth } \\
\text { conditions }\end{array}$} & \multirow{2}{*}{$\begin{array}{c}\text { Growth } \\
\text { phase }\end{array}$} & \multicolumn{7}{|c|}{ Respiratory activities (ngatoms oxygen consumed $/ \mathrm{min} / \mathrm{mg}$ of protein) with } \\
\hline & & glucose & pyruvate & succinate & L-lactate & D-lactate & formate & acetate \\
\hline \multirow[t]{2}{*}{ Haemin-replete } & Stationary & 385 & 490 & 142 & 1118 & 302 & 966 & 59 \\
\hline & Exponential & 180 & 200 & 13 & 400 & 50 & 400 & nd \\
\hline \multirow{2}{*}{ Haemin-limited } & Stationary & 28 & 37 & 0 & 37 & 39 & 0 & 19 \\
\hline & Exponential & 162 & 76 & 0 & 303 & 101 & 0 & nd \\
\hline
\end{tabular}

nd, Not determined.

Table III. Effect of growth conditions and growth phase on the respiratory activities of cell-free extracts derived from $H$. influenzae strain HM3

\begin{tabular}{|c|c|c|c|c|c|c|}
\hline \multirow{2}{*}{$\begin{array}{l}\text { Growth } \\
\text { conditions }\end{array}$} & \multirow{2}{*}{$\begin{array}{l}\text { Growth } \\
\text { phase }\end{array}$} & \multicolumn{5}{|c|}{$\begin{array}{l}\text { Respiratory activities } \\
\text { (ngatoms oxygen consumed } / \mathrm{min} / \mathrm{mg} \text { of protein) with }\end{array}$} \\
\hline & & NADH & succinate & L-lactate & D-lactate & formate \\
\hline \multirow[t]{2}{*}{ Haemin-replete } & Stationary & 421 & 23 & 303 & 10 & 66 \\
\hline & Exponential & 1240 & 22 & 134 & 9 & 109 \\
\hline \multirow{2}{*}{ Haemin-limited } & Stationary & 9 & 0 & 6 & 5 & 0 \\
\hline & Exponential & 86 & 0 & 42 & nd & 0 \\
\hline
\end{tabular}

nd, Not determined.

apparent lack of cytochromes (table I), suspensions of exponential phase, haemin-limited bacteria exhibited respiration rates with glucose and D- and L-lactate that were quantitatively similar to those exhibited by exponential phase organisms provided with quantities of haemin 40-fold higher (table II); however, the rate of pyruvate respiration was reduced in exponential phase, haemin-limited bacteria, and the respiration of formate and succinate remained undetectable.

Cell-free extracts prepared from bacteria grown under haemin-replete and haemin-limited conditions exhibited patterns of respiration (table III) similar to those expressed by intact cells (table II). The lack of succinate and formate respiration by cell-free extracts derived from haemin-limited bacteria is particularly striking. It is also notable that cell-free extracts derived from haemin-replete bacteria, and those derived from exponential phase organisms, respired NADH at rates greater than those exhibited by similar extracts derived from haemin-limited and stationary phase bacteria, respectively (table III). Membrane fractions isolated from stationary phase, haemin-replete $H$. influenzae strain HM3 also respired NADH, succinate and formate $(899,45$ and 140 ngatoms oxygen $/ \mathrm{min} / \mathrm{mg}$ of protein, respectively) whereas similar extracts prepared from haemin-limited bacteria exhibited greatly reduced rates of NADH respiration (6 ngatoms oxygen $/ \mathrm{min} / \mathrm{mg}$ of protein) and apparently no respiration of succinate or formate. NAD-stimulated respiration of NADPH was also demonstrated with particulate fractions from haemin-replete bacteria (NADPH, 22 ngatoms oxygen $/ \mathrm{min} / \mathrm{mg}$ of protein; $\mathrm{NADPH}+\mathrm{NAD}, 180$ ngatoms oxygen $/ \mathrm{min} / \mathrm{mg}$ of protein) but not with particulate fractions from haemin-limited bacteria (NADPH + / - NAD, 4 ngatoms oxygen $/ \mathrm{min} / \mathrm{mg}$ of protein). While reflecting the NADH oxidase activities, these results indicate that NADPH oxidation, mediated by membrane-bound pyridine nucleotide transhydrogenase, was greatly reduced in haemin-limited bacteria.

\section{Haemin limitation reduces the efficiency of glucose utilisation by $H$. influenzae}

While glucose respiration continues in bacteria essentially devoid of cytochromes, the reduced rates of glucose respiration (and the lack of cytochromes) appear to have an adverse effect on the efficiency of glucose utilisation as determined by the glucose growth yield. When the final biomass was determined by the initial glucose concentration (fig. 5), the growth yields obtained with $H$. influenzae strain HM3 provided initially with haemin $0.25 \mu \mathrm{g} / \mathrm{ml}$ were much reduced compared to those obtained with bacteria supplied initially with haemin $10 \mu \mathrm{g} / \mathrm{ml}$; these results compare favourably with those reported by White. ${ }^{2}$ The reduced efficiency of glucose utilisation by haemin-limited organisms coincided with changes in both the nature and concentrations of the organic acids that accumulated in the culture medium (table IV). Whereas spent medium derived from haemin-replete cultures contained more acetate than succinate and no lactate, similar samples derived from haemin-limited cultures contained more succinate than acetate and also contained lactate (table IV); formate was not detected in any sample of spent culture medium. Enzymatic assay for lactate demonstrated that the $\mathrm{D}$-isomer was present exclusively $(8.1 \mathrm{~mm}$; L-lactate $<0.05 \mathrm{mM})$. Similar 


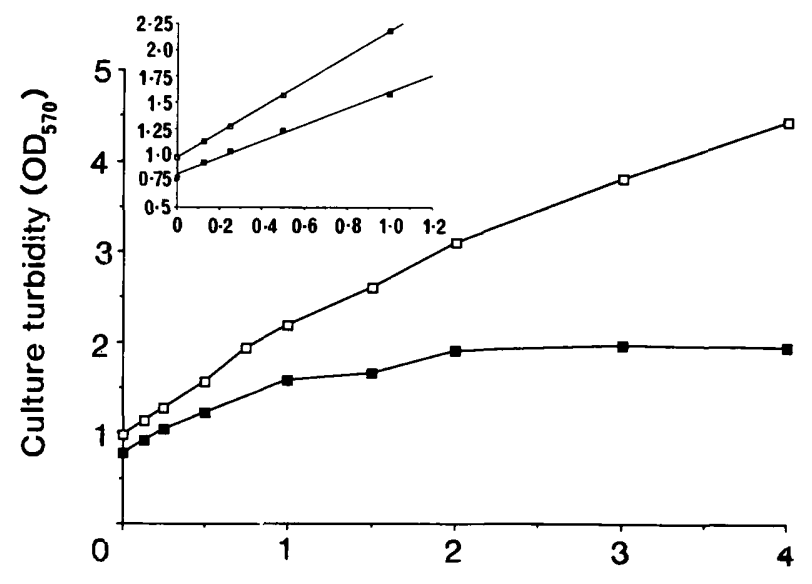

Initial concentration of added glucose ( $g / L)$

Fig. 5. Effect of initial haemin concentration on the glucose growth yield of $H$. influenzae strain HM3. Bacteria were grown in "glucosefree" BHI supplemented with NAD $10 \mu \mathrm{g} / \mathrm{ml}$, haemin either $10(\square)$ or $0.25 \mu \mathrm{g} / \mathrm{ml}(\boldsymbol{\square})$, and various quantities of glucose. Turbidity values are mean values $(n=3)$; SEM values are smaller than the symbols. The inset shows the yield at low initial glucose concentrations. The equations obtained from regression analysis are $\square, Y=1.21 X+0.97 ; \quad Y=0.78 X+0.81$.

Table IV. Effect of growth conditions on organic acid accumulation in cultures of $H$. influenzae strain HM3

\begin{tabular}{l|ccc}
\hline \multirow{2}{*}{ Growth conditions } & \multicolumn{3}{|c}{ Organic acid (mM) } \\
\cline { 2 - 4 } & Acetate & Succinate & Lactate \\
\hline Haemin-replete & 2.15 & 0.63 & ND \\
Haemin-limited & 0.68 & 1.90 & 7.40 \\
\hline
\end{tabular}

ND, none detected.

studies with three additional non-typable and two serotype b strains of $H$. influenzae revealed that the release of D-lactate, in response to haemin limitation, is not confined to strain HM3; while the five additional strains released different amounts of lactate, and less than strain HM3, in response to haemin limitation (range 1.2-4.3 mM; haemin-replete cultures, consistently $<0.05 \mathrm{~mm}$ ), the spent culture medium again contained, exclusively, the D-diastereoisomer (Llactate consistently $<0.05 \mathrm{~mm}$ ).

Finally, the release of lactate by $H$. influenzae strain HM3 was apparently not the result of enzyme induction, because the conversion of pyruvate to lactate by lactate dehydrogenase in soluble fractions derived from haemin-replete and haemin-limited organisms (mean 0.26 SEM 0.01 and 0.30 SEM $0.02 \mathrm{mmol} /$ $\mathrm{min} / \mathrm{mg}$ of protein, respectively) did not correlate with the appearance of $D$-lactate in culture fluids.

\section{Discussion}

Spectral analyses with subcellular fractions derived from $H$. influenzae strain HM3 grown in the presence of excess haemin, revealed that this organism can produce membrane-bound $b$-, $c$ - and $d$-type cytochromes and an easily-solubilised, CO-binding $c$-type cytochrome. These results are similar to those obtained with other Haemophilus strains, including another strain of $H$. influenzae. ${ }^{2,6,14-16}$ On the other hand, and in keeping with the results of White, ${ }^{2}$ $H$. influenzae strain HM3, provided with a low initial concentration of haemin, possessed flavin components but was essentially devoid of cytochromes.

In contrast to organisms grown under conditions of haemin sufficiency, intact cells of haemin-limited $H$. influenzae cannot respire exogenous $\mathrm{NADH}$, and haemin-limited $H$. canis, while retaining the capacity to respire NADH and lactate, does so only at reduced rates. ${ }^{2}$ In the present study, haemin limitation was associated with the selective loss of the capacities for formate and succinate respiration by both exponential phase and stationary phase bacteria, and also by cell extracts derived from these organisms. Furthermore, while stationary phase bacteria continued to respire the other substrates tested, the rates were reduced considerably. These results are not, perhaps, surprising considering the lack of cytochromes. Indeed, the patterns of respiration exhibited by cell-free extracts support the conclusion that the effects of haemin limitation on the respiratory capacities of intact cells are related more to the levels of cytochromes than to possible changes in the rates of substrate uptake. On the other hand, exponential phase, haemin-limited organisms were also virtually devoid of cytochromes but exhibited respiratory rates, with substrates other than formate or succinate, not dramatically different from those of exponential phase, haemin-replete organisms. Unless flavoproteins alone can account for these rates of substrate respiration by haemin-limited bacteria, ${ }^{2}$ it would appear that, in bacteria growing exponentially, undetectable amounts of cytochromes are capable of sustaining a level of respiratory metabolism similar to that exhibited by bacteria grown such that cytochromes are abundant. In this respect, Harrison ${ }^{17}$ has shown that a cellular level of cytochrome oxidase $d$ at the limit of detectability in reduced minus oxidised difference spectra might support a respiratory rate as high as $12.8 \mu$ gatoms oxygen consumed $/ \mathrm{mg}$ of dry bacterial weight $/ h$.

Despite the apparent anomaly outlined above, it is clear that reducing the initial supply of exogenous haemin to cultures of $H$. influenzae strain HM3 affects the respiratory metabolism of the organism. In this respect, the failure of haemin-limited organisms to respire formate and succinate is particularly interesting because this effect, and the other effects induced by haemin limitation, appeared to have no effect on the bacterial growth rate; while the specific loss of these respiratory capacities may be related to the lack of cytochromes, the resulting physiological consequences remain obscure.

A further consequence of the cellular changes that were brought about by reducing the supply of the porphyrin ring source was that haemin-limited $H$. 
influenzae strain HM3 utilised glucose less efficiently. This effect presumably reflects a shift towards a more anaerobic type of metabolism and, in keeping with such a conclusion, haemin limitation increased the organic acid content of the culture medium. It is also notable that haemin-limited growth was associated with the extracellular accumulation of D-lactate. Previous studies have demonstrated that $H$. influenzae (provided initially with haematin $2 \mu \mathrm{g} / \mathrm{ml}$ ) possesses only a partial tricarboxylic acid cycle and consequently, metabolises glucose to succinate, via oxaloacetate, and to acetate, via pyruvate. ${ }^{10}$ Our results indicate that this is also the case for $\boldsymbol{H}$. influenzae strain HM3, grown under both haemin-replete and haemin-limited conditions, and in addition, that the haemin-limited organism can also metabolise glucose to D-lactate, presumably via pyruvate. The apparent extent of D-lactate excretion suggests that the latter pathway represents a major pathway for the metabolism of glucose by the haemin-limited organism. Moreover, since haemin limitation had no effect on the lactate dehydrogenase activities of soluble fractions, it would appear that the accumulation of lactate is due not to the induction of a conventional, lactateproducing enzyme but rather to a possible change in the substrate fluxes through existing pathways coupled

\section{References}

1. Kilian M, Biberstein EL. Genus II. Haemophilus Winslow, Broadhurst, Buchanan, Krumwiede, Rogers and Smith 1917, 561. In: Krieg NR, Holt JG (eds) Bergey's Manual of systematic bacteriology, vol 1. Baltimore, Williams and Wilkins Co. 1984 : 558-569.

2. White DC. Respiratory systems in the hemin-requiring Haemophilus species. J Bacteriol 1963; 85: 84-96.

3. Murphy TF, Apicella MA. Nontypable Haemophilus influenzae: a review of clinical aspects, surface antigens, and the human immune response to infection. Rev Infect Dis 1987; 9: $1-15$.

4. Stull TL. Protein sources of heme for Haemophilus influenzae. Infect Immun 1987; 55: 148-153.

5. Stockley RA, Burnett D. Alpha ${ }_{1}$-antichymotrypsin in infected and noninfected sputum. Am Rev Resp Dis 1980; 122: $81-88$.

6. Niven DF. The cytochrome complement of Haemophilus parasuis. Can J Microbiol 1984; 30: 763-773.

7. Peterson GL. A simplification of the protein assay method of Lowry et al. which is more generally applicable. Anal Biochem 1977; 83: 346-356.

8. Poole RK, Bashford CL. Spectra. In: Bashford CL, Harris DA (eds) Spectrophotometry and spectrofluorimetry, a practical approach. Oxford, IRL Press. 1987: 23-48.

9. Jones CW, Redfearn ER. Electron transport in Azotobacter vinelandii. Biochim Biophys Acta 1966; 113: 467-481.

10. Tuyau JE, Sims W, Williams RAD. The acid end-products of glucose metabolism of oral and other haemophili. J Gen Microbiol 1984; 130: 1787-1793. with a reduced capacity for the respiration of the acid end-products.

The production of D-lactate by haemin-limited $H$. influenzae strain HM3, and by five other strains of $H$. influenzae, is particularly intriguing in that D-lactate, produced uniquely by bacteria ${ }^{18}$ has recently been detected in body fluids from sites of active $H$. influenzae infection. ${ }^{19}$ While other interpretations are possible, these results suggest that the phenotype expressed by $H$. influenzae growing extracellularly in vivo may be one induced by low porphyrin ring supply. In this respect, it is interesting to note that, in addition to the effects described here, haemin limitation also causes $H$. influenzae to express novel outer-membrane proteins. ${ }^{4}{ }^{20}$ It is conceivable that the organism growing in vivo may bear very little resemblance to organisms grown in vitro under conventional, nutrient-excess conditions and this should be borne in mind in attempts to relate the results obtained with $H$. influenzae grown in vitro with the situation in vivo.

This work was supported by grants from the Medical Research Council (to M.R.W.B. and T.O.), the Cystic Fibrosis Research Trust (to M.R.W.B. and T.O.), the Royal Society (to R.K.P.), the Science and Engineering Research Council (to R.K.P.) and the Natural Sciences and Engineering Research Council (to D.F.N.). T.O. thanks the Medical Research Council of Canada for a Postdoctoral Fellowship.

11. Denicola-Seoane A, Anderson BM. Purification and characterization of Haemophilus influenzae D-lactate dehydrogenase. J Biol Chem 1990; 265: 3691-3696.

12. Poole RK, Baines BS, Appleby CA. Haemoprotein b-590 (Escherichia coli), a reducible catalase and peroxidase: evidence for its close relationship to hydroperoxidase I and a 'cytochrome $a_{1} b$ ' preparation. J Gen Microbiol 1986 132: $1525-1539$.

13. Wood PM. Bacterial proteins with CO-binding $b$ - or $c$-type haem. Functions and absorption spectroscopy. Biochim Biophys Acta 1984; 768: 293-317.

14. White DC, Smith L. Hematin enzymes of Hemophilus parainfluenzae. J Biol Chem 1962; 237: 1332-1336.

15. Smith $\mathrm{L}$, White DC. Structure of the respiratory chain system as indicated by studies with Hemophilus parainfluenzae. J Biol Chem 1962; 237: 1337-1341.

16. Sinclair PR, White DC. Effect of nitrate, fumarate, and oxygen on the formation of the membrane-bound electron transport system of Haemophilus parainfluenzae. J Bacteriol $1970 ; 101$ : 365-372.

17. Harrison DEF. The regulation of respiration rate in growing bacteria. Adv Microbial Physiol 1976; 14: 243-313.

18. Dury DR, Wick AN. Chemistry and metabolism of $\mathrm{L}(+)$ and D(-) lactic acids. Ann N Y Acad Sci 1965; 119: 1061-1069.

19. Smith SM, Eng RHK, Campos JM, Chmel H. D-Lactic acid measurements in the diagnosis of bacterial infections. $J$ Clin Microbiol 1989; 27: 385-388.

20. Coulton JW, Pang JCS. Transport of hemin by Haemophilus influenzae type b. Curr Microbiol 1983; 9: 93-98. 